Acta HealthMedica (ISSN: 2414-6528) http://www.ActaHealthMedica.com

\title{
RELATIONSHIP BETWEEN WORK-FAMILY CONFLICT AND EMPLOYEE ENGAGEMENT IN FEMALE NURSES WORKING IN INTENSIVE CARE UNITS
}

\author{
Sara Sayar ${ }^{1}$, Faezeh Jahanpour ${ }^{2}$, Narges Maroufi ${ }^{3}$, Fatemeh Avazzadeh ${ }^{4}$
}

1: M.Sc. of Nursing, Member of Student Research Committee, Department of Nursing, Nursing \& Midwifery School, Bushehr University of Medical Sciences, Bushehr, Iran

2: Ph.D. of Nursing, Associate Professor, Department of Nursing, Nursing \& Midwifery School, Bushehr University of Medical Sciences, Bushehr, Iran

3: B.Sc. of Nursing, Salman-e-Farsi Hospital, Bushehr, Iran

4: B.Sc. of Nursing, Bushehr Medical \& Educational Heart Center, Affiliated with Bushehr University of Medical Sciences, Bushehr, Iran

\section{TYPE OF ARTICLE: ORIGINAL}

\begin{abstract}
Introduction: Employee engagement is an important indicator of performance in various organizational positions and leads to increasing the motivation to stay in the organization and job satisfaction. The aim of this study was to investigate the relationship between work-family conflict and employee engagement in female nurses working in intensive care units.

Methods: This cross-sectional study was carried out from January 2015 to 2016 in educational hospitals in Bushehr, Iran, on female nurses working in intensive care units. The Thomas Ladahl and Kejner questionnaire was used to measure employee engagement, and the Kamkar and Madani's questionnaire to measure workfamily conflict was used. Data were analyzed using SPSS 16 software via regression and Pearson correlation coefficient.

Results: One hundred twenty employee female nurses working in intensive care units were studied. The mean score of work-family conflict was $102 \pm 24$, and the mean score of female nurse's employee engagement was 34 \pm 5 . Findings showed a negative significant correlation between age and work history with employee engagement $(\mathrm{p}=0.00)$. Also, there was a negative significant correlation between work-family conflict and employee engagement $(\mathrm{p}=0.005)$.
\end{abstract}

Conclusion: Work-family conflict is a significant predictor of employee engagement, which, by adjusting, can increase the employee engagement in nurses.

KEYWORDS: Work-family conflict, Employee engagement, Nurses, Intensive care unit

\section{INTRODUCTION}

Family and job are considered as two significant social entities for each (1), so that employees are always under stressful conditions caused by the needs and demands of their organization. In the past, it was expected that the employees adapt themselves to the changing needs of the organizations; however, organizations are now making efforts to consider the needs of their employees (2). Job engagement is an important indicator of performance in various organizational positions and increases motivation to remain in an organization and enhances job satisfaction (3). There is still no specific definition proposed for engagement, especially job engagement, in nursing (2). Engagement is determined based on energy (versus fatigue), participation (versus cynicism), and further professional effectiveness (versus reduced professional effectiveness) (4). Schaufeli et al. first raised the concept of job engagement and considered it with three dimensions: vitality (high energy, willingness to strive), self-devotion (sense of participation in the job), and attraction (focus on the job). However, some recent studies provide evidence,

\section{Correspondence:}

Associate Professor Dr. Faezeh Jahanpour, Department of nursing, nursing \& midwifery School, Bushehr University of Medical Sciences, Bushehr, Iran.

Tel: +98.9177720846, Email: f jahanpour@yahoo.com

Received: February 21, 2016, Accepted: April 17, 2016, Published: June 2016

iThenticate screening: February 26, 2016, English editing: April 28, 2016, Quality control: May 10, 2016

(C) 2016 The Authors. This is an open access article under the terms of the Creative Commons Attribution-NonCommercialNoDerivs License, which permits use and distribution in any medium, provided the original work is properly cited, the use is non-commercial and no modifications or adaptations are made. 
which puts these three dimensions in a range $(4,5)$. Studies have shown that people today seek their success via engagement in multiple roles (including spouse, parent, and staff), and these roles sometimes overlap and interfere $(6,7)$. In other words, the individuals' experiences in one role influence their function and satisfaction in other roles (7). Work-family conflict is a two-way conflict, including work-family conflict and family-work conflict (8, 9). Work-family conflict is an intra-role conflict caused by the burdens imposed by work and family (9). It means that it is a form of inter-role conflict in which the total time dedicated to the job and the pressure imposed by that job disturbs family responsibilities (8). Parents, especially women, are more exposed to work-family conflicts (10, 11). Studies have shown that work-family conflicts have a negative correlation with job satisfaction, life, and marital life and a positive correlation with stress correlated with general psychological pressure, family, and work-related stress, physical symptoms, depression, and job burnout $(6,12,13)$. In a study conducted by Kamkar and Madani (2010) on 181 employees in the health network to predict work-family conflict and job engagement based on the success dimensions, it was revealed that those individuals who have more dedicated themselves to work and helping others suffer greater family problems. Interestingly, it was found out that those who were thinking of their personal success experienced less work-family conflict. In another study conducted by Alhani et al. (2011), based on the conventional content analysis of 16 nurses selected by purposive sampling, they showed that the nurses to reduce work-family conflict had made efforts individually. In some cases, these efforts resulted in reduced conflicts; however, in some other cases, individual efforts to reduce conflicts have been of no effect due to noncontinuous training and the relative competency in how to manage and deal with conflicts (14). Although there are job complications for all occupations, this issue is of paramount importance in professions relevant to human health (15). In this regard, the nurses, who are the key members of the health team (16), are prone to problems such as job burnout, physical, and mental stress, conflicts, and so on $(17,18)$. One of the sectors where nurses play an important role in their administration is the special care unit (including CCU, ICU, and hemodialysis) (16), which is inherently stressful (15) and can lead to job complications for nurses, who are usually facing the most emotional aspects of patients, working in these sectors (19). According to what has been noted here, and because a majority of nurses are women in the nursing profession, the nurses sometimes must spend all day in their workplace. Hence, this study aimed to investigate the relationship between work-family conflict and job engagement among female nurses working in critical care units of Bushehr training hospitals.

\section{MATERIAL AND METHODS}

\subsection{Research design and setting}

This cross-sectional study was conducted on female nurses working in critical care units of Bushehr training hospitals between Jan. 2015-2016.

\subsection{Sampling}

The sample size was determined 120 people of 310 female nurses based on the Morgan Table. They were selected by census method.

\subsection{Selection criteria}

Inclusion criteria consisted of having at least a bachelor's degree in nursing and employment in a special unit at the time of the study. The study exclusion criteria were also an unwillingness to participate in the study.

\subsection{Data collection}

Thomas Lodahl and Kejner's job engagement questionnaire, which specifies the length of time a person spent in his job, was used in this study. The questionnaire consists of 14 4-point Likert-scale items ranging from strongly agree to strongly disagree, and the scores range from 14 to 56. The higher score represents greater job engagement. The acquired scores 14-28, 29-32, and 33-56 are classified in low, average, and high levels, respectively. Experts confirmed its validity, and Cronbach's alpha was 86.81 regarding its reliability. To measure work-family conflict, Kamkar and Madani's questionnaire was used. The answers in this questionnaire range from "always" to "never" (for example, there is an accepted balance between my work and family time) and the scores of each subject is located between 30 (the minimum amount of conflict) and 150 (the maximum amount of conflict). The acquired scores 30-70, 71-110, and 111-150 are classified in low, average, and high levels, respectively. Its validity was confirmed by experts using correlation coefficient (0.96) and Cronbach's alpha coefficient (0.95).

\subsection{Research ethics}

To decide on samples to be included or excluded from the study, the researcher introduced himself and explained the objectives of research. In the case of acquiring patients' informed consent form and signing the form, Thomas 
Landel and Kejner's job engagement questionnaire and Kamkar and Madani's work-family conflict questionnaire were distributed among the sample nurses and collected after completion. It should be noted that this project was approved on January 5, 2016, by the Ethics Committee at Bushehr University of Medical Sciences (Ref. no.: R.Bpums.Rec.1394.123). Then, after presenting the recommendation letter of the Ethics Committee to Bushehr training hospitals, obtaining the nurse's consent and explaining the purpose of the study, the questionnaires was distributed among the nurses.

\subsection{Statistical analyses}

Data collected were analyzed by using the SPSS for Windows, (Released 2007. Version 16.0. Chicago, SPSS Inc). In this study, in addition to using descriptive statistics to examine the hypothesis, regression and Pearson correlation tests were also used. $\mathrm{P}<0.05$ was considered significant.

\section{RESULTS}

Out of 120 distributed questionnaires, 103 questionnaires were returned. The average age of female nurses participating in the study was $32 \pm 6$ years, and their average work experience was $8 \pm 5$ years. The mean score of work-family conflict was $102 \pm 24$ (at an intermediate level). The mean score of job engagement among those female nurses was $34 \pm 5$ positioned at an intermediate level. The correlation results showed a statistically significant positive relationship between age and work experience among the participants $(p=0.00)$. There was no significant correlation between age and work-family conflict scores $(\mathrm{p}=0.09)$. There was no significant relationship between background and work-family conflict $(\mathrm{p}=0.09)$. There was a significant negative relationship between age and engagement scores $(p=0.00)$. There was a significant negative relationship between background and engagement scores $(p=0.00)$. The findings revealed a negative correlation between the mean scores of work-family conflict for female nurses working in critical care units and the mean score of job engagement $(p=0.005)$. Table 1 shows the correlation (Pearson) coefficients for age, work experience, work-family conflict, and job engagement.

Table 1. Correlation (Pearson) coefficients for age, work experience, work-family conflict, and job engagement

\begin{tabular}{|c|c|c|c|c|c|c|c|c|}
\hline \multirow[t]{2}{*}{ Variables } & \multicolumn{2}{|c|}{ Employee Engagement } & \multicolumn{2}{|c|}{ Work-Family Conflict } & \multicolumn{2}{|l|}{ Age } & \multicolumn{2}{|c|}{ Work Experience } \\
\hline & $\mathrm{r}$ & p-value & $\mathrm{r}$ & p-value & $\mathrm{r}$ & p-value & $\mathrm{r}$ & p-value \\
\hline Employee engagement & 1 & --- & -0.255 & 0.005 & -0.239 & 0.007 & -0.277 & 0.002 \\
\hline Work-Family conflict & -0.255 & 0.005 & 1 & --- & 0.126 & 0.103 & 0.116 & 0.121 \\
\hline Age & -0.239 & 0.007 & 0.126 & 0.103 & 1 & --- & 0.833 & 0.000 \\
\hline Work experience & -0.277 & 0.002 & 0.116 & 0.121 & 0.833 & 0.000 & 1 & --- \\
\hline
\end{tabular}

The bivariate correlation coefficient for the linear combination of work-family conflict and background with job engagement was equal to $0.035(\mathrm{t}=-.127, \mathrm{~F}=7.26)$, which is significant at $\mathrm{p}<0.001$. The regression coefficient of the above linear combination for the work-family conflict was $\mathrm{B}=-.053(\mathrm{t}=-2.39)$, which is significant at the statistical level $\mathrm{p}<0.01$. For the second including variable, i.e., background, the values $\mathrm{B}=-0.24$ and $\mathrm{t}=-2.66$ are significant at the statistical level $\mathrm{p}<0.01$. Accordingly, it can be concluded that there is a significant relationship between the linear combination of predictor variables (work-family conflict and background) and criterion variables (job engagement). Given that age and experience have a direct relationship, the variable background was only used in the model (Table 2).

Table 2. Relationship of work experience and work-family conflict with employee engagement by forward method

\begin{tabular}{|c|c|c|c|c|c|c|}
\hline \multirow{2}{*}{$\begin{array}{l}\text { Criterion } \\
\text { variable }\end{array}$} & \multirow{2}{*}{$\begin{array}{l}\text { Predictor } \\
\text { variables }\end{array}$} & \multirow{2}{*}{$\begin{array}{l}\text { Multivariate } \\
\text { correlation } \\
\text { coefficient }\end{array}$} & \multirow{2}{*}{$\begin{array}{l}\text { Determination } \\
\text { coefficient }\end{array}$} & \multirow{2}{*}{$\begin{array}{l}\text { F ratio } \\
\text { significance } \\
\text { level }\end{array}$} & \multicolumn{2}{|c|}{ Regression coefficients } \\
\hline & & & & & $\begin{array}{l}\text { Work } \\
\text { experience }\end{array}$ & $\begin{array}{l}\text { Work- } \\
\text { Family } \\
\text { conflict }\end{array}$ \\
\hline \multirow[t]{2}{*}{$\begin{array}{l}\text { Employee } \\
\text { engagement }\end{array}$} & $\begin{array}{l}\text { Work } \\
\text { experience }\end{array}$ & 0.277 & 0.077 & 8.38 & $\begin{array}{l}B=-0.26 \\
t=-2.89 \\
p<0.005\end{array}$ & ------- \\
\hline & $\begin{array}{l}\text { Work- } \\
\text { Family } \\
\text { conflict }\end{array}$ & 0.356 & 0.127 & 7.26 & $\begin{array}{l}B=-0.242 \\
t=-2.66 \\
p<0.01\end{array}$ & $\begin{array}{l}B=-0.053 \\
t=-2.39 \\
p<0.01\end{array}$ \\
\hline
\end{tabular}




\section{DISCUSSION}

In this study, the correlation between work-family conflict and job engagement of female nurses working at a special unit of Bushehr training hospitals was investigated. The results of descriptive statistics showed that female nurses' work-family conflict scores are at an intermediate level and comply with the results of the study conducted by Rastegar Khaled. The job engagement score was at an intermediate level, which is consistent with Keshtkaran's findings. There was a significant negative correlation between age and work experience and job engagement. In other words, nurses with lower age and experience levels are more engaged in their jobs; however, Tuisku's study did not confirm this claim. He concluded that older nurses have higher levels of job engagement and successful experiences. The correlation findings also showed a significant negative correlation between the mean scores of work-family conflict and job engagement. This means that the lower the work-family conflict felt by nurses is, the greater their engagement to their job will be. Also, when the variable work experience was added in the linear regression combination, the multivariate correlation coefficient increased, which approves the impact of the variable work-family conflict on the job engagement. This finding is consistent with the findings of studies conducted by Salahiyan (20), Motasharrei (21), Naeimi (22), Devi (23), Mehrabizadeh Honarmand. These studies showed that the work-family conflict can overshadow job performance, satisfaction, and engagement and has an indirect relationship with them. Petek (2016) introduced the work-family conflict as one of the biggest stressors (10), which can be affected by occupational, organizational, and personal factors. On the one hand, the studies conducted by Devi (23), Naeimi (22), Goh (24), and Yildirim (25) determined that nurses' high workload and unspecified schedules are the most important factors increasing work-family conflict. However, some strategies, such as increasing organization and supervision team supports as well as strengthening adaptation skills can reduce this conflict. As a result, nurses' job engagement can be increased by decreasing work-family conflicts through reducing the nurses' workload, establishing a balance between their work and personal life programs, supporting and enriching cognitive skills and adaptability. Job engagement, in turn, creates interest in the job and a tendency to remain in a job position and enhances performance (2). The results of Parks' et al. study showed that employees with higher levels of job engagement sometimes ignore work-life balance and sacrifice their lives for their jobs and organization goals, and its consequence will benefit the organizations (26) because the nurses who are more engaged in their jobs would have a greater incentive to work and provide a higher quality of caring (2). One of the limitations of this study is the small sample size, which makes it difficult to generalize the findings to a larger population. It is suggested that this study is replicated with a larger sample size on other nurses.

\section{CONCLUSIONS}

According to our findings, we conclude that work-family conflict can lead to lower job engagement in female nurses working in intensive care units. Regarding the vital role of nurses among other health care team members, especially nurses in critical care units who are always facing difficult and critical conditions, authorities are expected to make decisions and policies in order to reduce work conflicts for the nurses and promote organizational goals and improve the quality of health services through increasing their job satisfaction and engagement.

\section{ACKNOWLEDGMENTS:}

We would like to express our gratitude to the research deputy of Bushehr University of Medical Sciences, who paved the way for this study through approving the project proposal. We also thank the Centre for Clinical Studies at Shohadaye Khalij Fars Hospital, contributing to this study and to the nurses of critical care units at Bushehr training hospitals.

\section{CONFLICT OF INTEREST:}

There is no conflict of interest to be declared.

\section{AUTHORS' CONTRIBUTIONS:}

All authors contributed to this project and article equally. All authors read and approved the final manuscript.

\section{REFERENCES:}

1) Kan D, Yu X. Occupational Stress, work-family conflict and depressive symptoms among chinese bank employees: the role of psychological capital. International journal of environmental research and public health. 2016; 13(1): 134. doi: 10.3390/ijerph13010134. PMid: 26784215. PMCid: PMC4730525.

2) Sohrabizadeh S, Sayfouri N. Antecedents and consequences of work engagement among nurses. Iranian Red Crescent medical journal. 2014; 16(11): 16351. doi: 10.5812/ircmj.16351. PMid: 25763212. PMCid: PMC4329961. 
3) Montgomery A, Spanu F, Baban A, Panagopoulou E. Job demands, burnout, and engagement among nurses: A multi-level analysis of ORCAB data investigating the moderating effect of teamwork. Burnout research. 2015; 2(2-3): 71-9. doi: 10.1016/j.burn.2015.06.001. PMid: 26877971. PMCid: PMC4710673.

4) Mojsa-Kaja J, Golonka K, Marek T. Job burnout and engagement among teachers - Worklife areas and personality traits as predictors of relationships with work. International Journal of Occupational Medicine and Environmental Health. 2015; 28(1): 102-19. doi: 10.13075/ijomeh.1896.00238. PMid: 26159952.

5) Babaei Khalaji M, Ahmadi S, Shahbazi M. Investigation of the Effective Factors on Employee Engagement of Nurses in Farabi Eye Hospital affiliated to Tehran University of Medical Sciences. Journal of Public Administration. 2014; 5(4): 39-56.

6) Bethge M, Borngraber Y. Work-family conflicts and self-reported work ability: cross-sectional findings in women with chronic musculoskeletal disorders. BMC musculoskeletal disorders. 2015; 16: 58. doi: 10.1186/s12891-015-0515-4. PMid: 25888117. PMCid: PMC4373097.

7) Oreyzi H, Javanmard S, Nouri A. Relationship of Work-Family Conflict with Organizational Justice, Organizational Commitment and Vitality, by Considering the Role of Expatriate and Normal Work Schedules. JSR. 2014; 15(56): 105-15.

8) Hao J, Wu D, Liu L, Li X, Wu H. Association between Work-Family Conflict and Depressive Symptoms among Chinese Female Nurses: The Mediating and Moderating Role of Psychological Capital. International journal of environmental research and public health. 2015 Jun 12; 12(6): 6682-99. doi: 10.3390/ijerph120606682. PMid: 26075725. PMCid: PMC4483724.

9) Mache S, Bernburg M, Vitzthum K, Groneberg DA, Klapp BF, Danzer G. Managing work-family conflict in the medical profession: working conditions and individual resources as related factors. BMJ open. 2015; 5(4): e006871.

10) Aazami S, Shamsuddin K, Akmal S. Examining behavioural coping strategies as mediators between workfamily conflict and psychological distress. The Scientific World Journal. 2015; 1(1): 1-7. doi: $10.1155 / 2015 / 343075$.

11) Alhani F, Vanaki Z. Decline of Self-efficacy: the Consequence of Nursing Work-family Conflict. Journal of Qualitative Research in Health Sciences. 2012; 1(2): 135-47.

12) Allaf Javadi M, Parandeh A, Ebadi A, Haji Amini Z. Comparison of life quality between special care units and internal-surgical nurses. Journal of Critical Care Nursing. 2010; 3(3): 9-10.

13) Petek D, Gajsek T, Petek Ster M. Work-family balance by women GP specialist trainees in Slovenia: a qualitative study. BMC medical education. 2016; 16(1): 31. doi: 10.1186/s12909-016-0551-2. PMid: 26821533. PMCid: PMC4730732.

14) Annink A, den Dulk L, Steijn B. Work-Family Conflict Among Employees and the Self-Employed Across Europe. Social indicators research. 2016; 126: 571-93. doi: 10.1007/s11205-015-0899-4. PMid: 26912943. PMCid: PMC4751170.

15) Moen P, Kaduk A, Kossek EE, Hammer L, Buxton OM, O'Donnell E, et al. Is work-family conflict a multilevel stressor linking job conditions to mental health? Evidence from the work, family and health network. Research in the sociology of work. 2015; 26: 177-217. doi: 10.1108/s0277-283320150000026014.

16) Mohammadi Gh. R. , Ebrahimian A. A. , Mahmoudi H. Evaluating the knowledge of intensive care unit nursing staffs. Iranian Journal of Critical Care Nursing. 2009; 2(1): $41-6$.

17) Amini F, Farah bakhsh K, Nikoozadeh kordmirza E. Comparative analysis of life satisfaction, resilience and burnout among intensive and other units nurses. Quarterly Journal of Nersing Management. 2013; 1(4): 9-17.

18) Mahmoodi H, Ebrahimian aa, soleimani M, Ebadi a, Hafezi S, Feizi F, et al. examine the factors of job motivation in nurses of critical care unite Journal of Behavioral Sciences. 2008; 1(2): 15-6.

19) Mohammadi M, Mazloumi A, Zeraati H. Designing questionnaire of assessing mental workload and determine its validity and reliability among ICUs nurses in one of the TUMS's hospitals. Journal of School of Public Health and Institute of Public Health Research. 2013; 11(2): 87-96.

20) Salahian A, Kajbaf M, Nouri A, Molavi H, Hasanzadeh M. The Study of the Effective Organizational Factors on the Conflict between Work and Family. Clinical Psychology \& Personality (Daneshvar Raftar). 2010; 17(43): 21-30.

21) Motesharreie M, Neisa A, Arshadi N. Testing of indirect effect of work-family conflict on life satisfactiona multi-mediator model. Clinical Psychology \& Personality. 2013; 20(8): 75-86.

22) Naeimi G, Nazari A, Sanai ZB. A study of relationship between qulaity of work life and work-family conflict with job performance among married men employee. Quarterly Journal of Career \& Organizational Counseling. 2012; 4(10): 57-72. 
23) Devi KR, Rani SS. The Impact of Organizational Role Stress and Work Family Conflict: Diagnosis Sources of Difficulty at Work Place and Job Satisfaction among Women in IT Sector, Chennai, Tamil Nadu. Procedia-Social and Behavioral Sciences. 2016; 219: 214-20. doi: 10.1016/j. sbspro.

24) Goh Z, Ilies R, Wilson KS. Supportive supervisors improve employees' daily lives: The role supervisors play in the impact of daily workload on life satisfaction via work-family conflict. Journal of Vocational Behavior. 2015; 89: 65-73. doi: 10.1016/j.jvb.2015.04.009.

25) Yildirim D, Aycan Z. Nurses' work demands and work-family conflict: A questionnaire survey. International journal of nursing studies. 2008; 45(9): 1366-78. doi:10.1016/j.ijnurstu.2007.10.010. PMid: 18262529.

26) Parkes LP, Langford PH. Work-life bal ance or work-life alignment? A test of the importance of work-life balance for employee engagement and intention to stay in organisations. Journal of Management \& Organization. 2008; 14(03): 267-84. doi: 10.1017/S1833367200003278. 